Научная статья

УДК 37.013.77(571.54)

DOI: $10.18101 / 2307-3330-2021-2-4-9$

\title{
ОБЕСПЕЧЕНИЕ ПСИХОЛОГИЧЕСКИ БЕЗОПАСНОЙ И КОМФОРТНОЙ СРЕДЫ В «СПЕЦИАЛЬНОЙ (КОРРЕКЦИОННОЙ) ОБЩЕОБРАЗОВАТЕЛЬНОЙ ШКОЛЕ № 3» Г. УЛАН-УДЭ
}

\author{
(C) Апанасенко Светлана Сергеевна \\ педагог, \\ Специальная (коррекционная) общеобразовательная школа № 3 \\ Россия, 670002, г. Улан-Удэ, улица Буйко, 25 \\ sharnikova@yandex.ru

\section{(C) Хоженоева Альбина Николаевна} \\ педагог-психолог, \\ Специальная (коррекционная) общеобразовательная школа № 3 \\ Россия, 670002, г. Улан-Удэ, ул. Буйко, 25 \\ albina.hozhenoeva@yandex.ru
}

\begin{abstract}
Аннотация. В статье рассматриваются особенности развития психологическикомфортной безопасной среды в условиях специальной коррекционной школы. Выделена категория «психологическая безопасность образовательной среды», являющаяся интегративной характеристикой, определяющей психическое здоровье субъектов образования. Приведены примеры обеспечения психологически безопасной и комфортной среды в ГБОУ «СКОШ № 3» по таким направлениям работы, как психологическая профилактика, психологическая коррекция, психологическое консультирование, психологическая реабилитация, социально-психологическое обучение. Раскрыты специфика и возможности реализации данных направлений в условиях конкретного образовательного учреждения. Имеются сведения о проведении мониторинга уровня безопасности образовательной среды в школе. Показана необходимость системной коррекционной работы в правильно организованной школьной среде, включающей взаимодействие всех субъектов образовательного процесса, для создания позитивного психологического климата.

Ключевые слова: образование, безопасность, учащиеся, школа, педагог, психологический комфорт, профилактика, консультирование, реабилитация, коррекция.
\end{abstract}

\section{Для цитирования}

Апанасенко С. С., Хоженоева А. Н. Обеспечение психологически безопасной и комфортной среды в «специальной (коррекционной) общеобразовательной школе № 3» г. Улан-Удэ // Вестник Бурятского государственного университета. Образование. Личность. Общество. 2021. № 2. С. 4-9.

В последнее время многие ученые в области педагогики и психологии, учителя говорят и пишут о проблеме психологической безопасности в образовательных организациях. В частности, речь идет об индивидуальном подходе к ученику в процессе обучения, о создании в школе атмосферы психологического комфорта. В психологической науке понятие «безопасность» активно исследуется с середины XX в. Данную проблему раскрывали в своих трудах такие ученые, как А. Маслоу, Э. Фромм, К. Хорни, И. А. Баева, Е. В. Бурмистрова и другие ис- 
C. С. Апанасенко, А. Н. Хоженоева. Обеспечение психологически безопасной и комфортной среды в «специальной (коррекционной) общеобразовательной школе № 3» г. Улан-Удэ

следователи. Существует немало мнений и определений понятия «безопасность». Так, например, в законе Российской Федерации «О безопасности» данное понятие рассматривается как состояние защищенности жизненно важных интересов личности, общества и государства от внешних и внутренних угроз [7]. В словаре Д. Н. Ушакова термин «безопасность» определяется как «отсутствие опасности», но также и как «предупреждение опасности, условия, при которых не угрожает опасность» [6].

Тема социальной безопасности в исследованиях ученых занимает центральное место. В ее структуру входит и психологическая безопасность, т. е. выполнение социальными институтами своих функций по удовлетворению потребностей, интересов, целей всего населения страны [3]. Немаловажное место в ряду социальных институтов занимают образовательные организации. Образовательная среда - часть социокультурной среды и определяется исследователями как комплекс специально организованных психолого-педагогических условий, в результате взаимодействия с которыми происходит развитие и становление личности [4].

Оптимальным условием для развития личности является психологическая безопасность среды. И. А. Баева разработала концепцию и структурную модель психологической безопасности образовательной среды как основу для создания системы психолого-педагогического сопровождения детей в данных условиях. В настоящее время сопровождение рассматривается как система профессиональной деятельности психолога, направленной на создание социальнопсихологических условий для успешного обучения и психологического развития ребенка в ситуации школьного взаимодействия [1]. Данная концепция успешно реализуется в ГБОУ «СКОШ № 3» г. Улан-Удэ. Центральное место в ней занимает психологически здоровая личность, которая взаимодействует с другими субъектами образовательного процесса на основе диалога и принципов сотрудничества.

Обеспечение психологически безопасной и комфортной среды в ГБОУ «СКОШ № 3» определяется направлениями работы:

Психологическая профилактика - содействие полноценному развитию личности всех участников учебно-воспитательного процесса, предупреждение возможных личностных деформаций в процессе взаимодействия, помощи в осознании деструктивного влияния психологического насилия [5]. Данное направление реализовывается в рамках комплексной программы по профилактике суицидального поведения детей и подростков с интеллектуальными нарушениями. Работа проводится через групповые занятия для учащихся, выступления на собраниях для родителей («Особенности адаптации обучающихся к новым условиям обучения»; «О психологической готовности учащихся 4-го класса к обучению в основной школе»; «Онлайн-площадка по профилактике деструктивного поведения»; «Профилактика агрессивных проявлений в подростковом возрасте» и др.), проведение семинаров для педагогов, оформление информационного стенда, публикации памяток и рекомендаций на сайте школы, выпуск буклетов («Памятка классному руководителю при работе с детьми, находящимися в кризисном состоянии», «Памятка родителям по взаимодействию с ребенком-подростком 
"Мы вместе"», «Рекомендации педагогам по профилактике агрессивности»). Мероприятия реализованы согласно плану работы.

Психологическое консультирование - оказание помощи участникам воспитательно-образовательного процесса в самопознании, позитивном самоотношении, адаптации к трудным жизненным условиям, достижении эмоциональной комфортности, построении конструктивных межличностных отношений [5]. В ГБОУ «СКОШ № 3» психологами проводятся индивидуальные консультации для педагогов, родителей, групповые консультации для обучающихся. Основные темы консультаций: «Межличностные отношения в классе», «Формирование коммуникативной культуры учеников», «Адаптация школьников 1-х и 5-х классов к новым социальным условиям», «Профориентация, определение склонностей, интересов», «Психологические особенности подросткового возраста», «Профилактика вредных привычек у школьников» и др.

Психологическая коррекция - активное психолого-педагогическое воздействие, направленное на устранение отклонений в личностном и профессиональном развитии, на гармонизацию психического здоровья и устранение деформаций. Психолого-педагогическая коррекция - это форма совместной профессиональной деятельности педагога, психолога и родителей, основанная на системе психологических воздействий с целью исправления нарушений психического развития с опорой на знания возрастной, социокультурной и индивидуальной норм развития [5]. В рамках данного направления реализуются коррекционно-развивающие программы: «Коррекционная программа в соответствии со Стандартом», «Введение в мир профессий», «Адаптация учащихся 1-го класса», «Адаптация учащихся 5-го класса» и др.

Психологическая реабилитация - воздействие на участников образовательного процесса, мобилизующее личностные адаптационные механизмы при переживании психотравмирующих обстоятельств [5]. На базе ГБОУ «Специальная (коррекционная) общеобразовательная школа № 3» был создан и осуществляет свою деятельность Центр комплексной реабилитации и абилитации детейинвалидов (направление - дети с аутизмом). Для ведения консультативной и просветительской деятельности привлекаются педагоги и специалисты школы, имеющие практический опыт работы с детьми с РАС. В рамках реализации мероприятий Комплексной программы по реабилитации и абилитации детейинвалидов было приобретено специальное оборудование: интерактивные панели, интерактивный пол, тоннель для подлезания, кнопка-коммуникатор, набор для детей с РАС и др.

Социально-психологическое обучение - активное групповое воздействие, направленное на помощь в усвоении эффективных способов и приемов взаимодействия, свободных от проявления психологического насилия, создающее социально-психологическую умелость, реализующее принцип развивающего воспитания и защищенности личности и обеспечивающее поддержку в решении возрастных, жизненных и профессиональных проблем [5]. Традиционно в данной школе проходит «Неделя толерантности». Целью проведения мероприятия является активизация навыков видеть хорошее в другом человеке, находить слова, выражающие восхищение, удивление, уважение; развитие чувства единения и успешности. В рамках Недели толерантности были проведены акции «Браслеты 
C. С. Апанасенко, А. Н. Хоженоева. Обеспечение психологически безопасной и комфортной среды в «специальной (коррекционной) общеобразовательной школе № 3» г. Улан-Удэ

дружбы», «Стена гласности», «Коробка добра и милосердия» для БРО «КонекГорбунок»; игра «Следопыт», акция «Радость - это...», линейка «Подведение итогов Недели». Еще одно интересное мероприятие «День позитива» проходит под девизом: «Улыбнись жизни - ты ей нравишься!!!», программа которого включает следующие разделы:

- акция «Корзина добрых пожеланий»: с самого утра в фойе школы педагоги, учащиеся и родители получали конфеты с пожеланиями и дарили друг другу хорошее настроение;

- артстудия «Веселый художник»: на переменах студенты БРПК (Бурятского республиканского педагогического колледжа) художественно-графического отделения рисовали интересные картинки, смайлики, рисовали нитками красивые цветы, складывали из бумаги воздушных бабочек;

- акция «Солнечный фотограф»: на переменах каждый класс должен был изобразить пантомиму на предложенную тему;

- конкурс «Радуга настроения»: во второй половине дня учащиеся рисовали «Радугу настроения», придумывали лозунг ко Дню позитива.

Таким образом, данная программа способствует улучшению эмоционального состояния, снижению беспокойства, снятию нервного возбуждения и тревожности учащихся. Она усиливает антисуицидальные барьеры, позволяет использовать потенциал самого ребенка для осознания им ценности жизни и здоровья, необходимости выработки и закрепления социальных навыков и умений, способствующих устойчивой адаптации в социуме. Всем участникам образовательных отношений нравится участвовать в предлагаемых мероприятиях. В целях профилактики и коррекции кризисных состояний психологической службой школы проводились индивидуальные занятия, индивидуальные консультации.

Необходимо отметить, что каждый год в нашей школе проводится мониторинг уровня безопасности образовательной среды. С целью изучения образовательной среды и выявления оценки со стороны педагогов, учащихся и их родителей состояния ее психологической безопасности для каждого участника образовательного процесса подготовлен банк эмпирических методик: цветотест М. Люшера и опросник для учащихся «Психологическая диагностика образовательной среды», опросник для педагогов, опросник для родителей (автор И. А. Баева). Процедура получения обратной связи соответствует необходимым требованиям психологической этики: это обязательное соблюдение анонимного проведения анкетирования взрослых; бланки опросников были даны на одинаковых стандартных листах; листы с ответами опрашиваемые опускали в специальный ящик. Обработка результатов осуществлялась психологами школы. Результаты данного исследования показали, что ученики, родители и педагоги оценили высокую степень психологической безопасности ГБОУ «СКОШ № 3». Также были выявлены наиболее значимые характеристики образовательной среды с точки зрения участников опроса. Для учеников наиболее важным является показатель «возможность получать поддержку и помощь педагогов», они отметили, что «обучение в школе приносит радость и удовлетворение». Для учителей самые важные характеристики - это взаимоотношения с учениками. Для родителей самой важной характеристикой являются взаимоотношения с учителями. 
Анализируя результаты психолого-педагогической работы с учащимися, родителями, педагогами ГБОУ «СКОШ № 3», можно сделать вывод, что для создания позитивного психологического климата необходима системная коррекционная работа в правильно организованной образовательной среде, включающая взаимодействие всех субъектов педагогического процесса.

Таким образом, результат доброжелательных, доверительных отношений в условиях психологической комфортности в образовательной среде: для ребенка - сохранение психического здоровья; для педагога - удовлетворенность, видимый результат в лице счастливых, благодарных учеников и их родителей.

Лuтература

1. Баева И. А. Психологическая безопасность образовательной среды: развитие личности: монография. Санкт Петербург: Нестор-История, 2011. 272 с. Текст: непосредственный.

2. Баева И. А., Волкова Е. Н., Лактионова Е. Б. Психологическая безопасность образовательной среды: учебное пособие. Москва: Экон-Информ, 2009. 248 с. URL: http://pedlib.ru/index2.php?dir=7/0289\&num_page=1\&part=Books (дата обращения: 25.09.2021). Текст: непосредственный.

3. Бобрышева И. В. К вопросу о психологической безопасности образовательной среды // Гуманно-личностное пространство сопровождения семьи в реалиях XXI века: материалы I Региональных педагогических чтений 13-14 ноября 2008 г.; под общей редакцией Е. С. Евдокимовой. Волгоград: Волгоградское научное изд-во, 2009. С. 26-28. Текст: непосредственный.

4. Зотова Н. Г. Ценностно-смысловое пространство образовательной среды // Гуманно-личностное пространство сопровождения семьи в реалиях XXI века: материалы I Региональных педагогических чтений 13-14 ноября 2008 г.; под общей редакцией Е. С. Евдокимовой. Волгоград: Волгоградское научное изд-во, 2009. С. 11-13. Текст: непосредственный.

5. Непрокина И. В., Болотникова О. П., Ошкина А. А. Безопасная образовательная среда: моделирование, проектирование, мониторинг: учебное пособие. Тольятти: Изд-во ТГУ, 2012. 92 с. Текст: непосредственный.

6. Ушаков Д. Н. Толковый словарь «Большой толковый словарь русского языка. Современная редакция». URL: https://gufo.me/dict/ushakov (дата обращения: 25.09.2021). Текст: электронный.

7. Федеральный закон от 28.12.2010 № 390-Ф3 «О безопасности» // Российская газета. 2010. 29 дек. № 295. Текст: непосредственный.

Статья поступила в редакцию 05.06.2021; одобрена после рецензирования 05.07.2021; принята к публикациии 29.11.2021.

PROVIDING PSYCHOLOGICALLY SAFE AND COMFORTABLE ENVIRONMENTS IN SPECIAL (REMEDIAL) SECONDARY GENERAL SCHOOL No. 3

Svenlana S. Apanasenko

Teacher,

Special (Remedial) Secondary General School No. 3

25 Buiko St., Ulan-Ude 670002, Russia

szharnikova@yandex.ru 
C. С. Апанасенко, А. Н. Хоженоева. Обеспечение психологически безопасной и комфортной среды в «специальной (коррекционной) общеобразовательной школе № 3» г. Улан-Удэ

\author{
Albina N. Khozhenoyeva \\ Educational Psychologist, \\ Special (Remedial) Secondary General School No. 3 \\ 25 Buiko St., Ulan-Ude 670002, Russia \\ albina.hozhenoeva@yandex.ru
}

Abstract. The article discusses the features of providing psychologically comfortable and safe environments in a special (remedial) secondary school. Focusing on the category of «psychological safety of learning environment» as an integrative characteristics determining the mental health of the subjects of learning, we provide the examples of psychologically safe and comfortable environments at State Budgetary Educational Institution "Special (Remedial) Secondary General School No. 3" in such fields as psychological prevention, psychological treatment, psychological counseling, psychological rehabilitation, social and psychological training. We have revealed the specifics and possibilities of these activities in the conditions of a particular educational institution. The article also provides information on the monitoring of the level of safety in the school educational environments. The research shows that to create a positive psychological climate at school, remedial training should be carried out in well-structured environment, and involve all the subjects of educational process.

Keywords: education, safety, students, remedial school, teacher, psychological comfort, prevention, counseling, rehabilitation, correction.

\title{
For citation
}

Apanasenko S. S., Khozhenoyeva A. N. Providing Psychologically Safe and Comfortable Environments in Special (Remedial) Secondary General School No. 3. Education. Person. Society. 2021; 2: 4-9 (In Russ.).

The article was submitted 05.06.2021; approved after reviewing 05.07.2021; accepted for publication 29.11.2021. 